\title{
Analisa Pengaruh Penyerapan Air Sungai Mahakam terhadap Kekuatan Tarik Material Komposit dengan Variasi Perbandingan Matriks dan Hardener
}

\author{
Zulkifli $^{1, a}$ dan Hadi Hermansyah ${ }^{1, b}$ \\ ${ }^{1}$ Jurusan, Teknik Mesin, Politeknik Negeri Balikpapan, Jl. Soekarno Hatta Km. 8, Balikpapan 76126 \\ azulkifli.as@poltekba.ac.id \\ bhermansyah_hadi@yahoo.com
}

\begin{abstract}
This research purpose is to analyze the effect of immersion for 9 days on tensile strength of the epoxy resin composite materials without fiber reinforcement with a $65: 35$, 70:30, 75:25 ratio; and simulate the rate of absorption of water for 9 days in epoxy resin composite materials without fiber reinforcement with a ratio $65: 35,70: 30,75: 25$. The Polymers used is epoxy resin type, then molded with a size of $200 \times 200 \times 4$ $\mathrm{mm}$ with resin and hardener ratio $65: 35,70: 30$, and $75: 25$. Then the composite plate is immersed in an aquarium containing water from the river Mahakam for 9 days, the test procedures River water absorption refers to the ASTM D 570 - 98. After 9 days plate was cut to form polymer composite beam according to the standard ASTM D638-02 (type 1). Each variable will be tested for 3 times. Based on immersion testing performed on specimens 65:35 mass increases $0.4135 \%, 0.2677 \%$ increases on specimen 70:30 and 75:25 specimens increased $0.4 \%$, while the tensile test results before $65: 35$ specimens immersed is 32.333 MPa after being soaked down into $24.46 \mathrm{MPa}$, tensile test before specimens 70:30 immersed is $36.3 \mathrm{MPa}$ after immersion dropped to 34793 MPa, tensile specimens 75:25 before immersed is $32.993 \mathrm{MPa}$ after immersion dropped to $25803 \mathrm{MPa}$.
\end{abstract}

Keywords: Composites, Immersion, tensile test, ASTM.

\footnotetext{
Abstrak- Penelitian ini bertujuan untuk menganalisa pengaruh perendaman selama 9 hari terhadap kekuatan tarik material komposit resin epoksi tanpa penguat serat dengan perbandingan $65: 35,70: 30,75: 25$; dan mensimulasikan laju penyerapan air selama 9 hari pada material komposit resin epoksi tanpa penguat serat dengan perbandingan 65:35, 70:30, 75:25.Polimer yang digunakan jenis resin epoksi, selanjutnya dicetak dengan ukuran $200 \times 200 \times 4 \mathrm{~mm}$ dengan perbandingan antara resin dan hardener yaitu $65: 35,70: 30$, dan 75:25. Lalu pelat komposit direndam dalam wadah akuarium yang berisi air dari sungai Mahakam selama 9 hari, prosedur pengujian penyerapan Air sungai ini mengacu pada ASTM D 570 - 98. Setelah 9 hari pelat dipotong membentuk balok komposit polimer sesuai standar ASTM D638-02 (type 1). Setiap variabelakan diuji sebanyak 3 kali. Berdasarkan pengujian perendaman yang dilakukan pada spesimen 65:35 massanya bertambah $0.4135 \%$, specimen 70:30 bertambah 0.2677 \%, dan
}

spesimen 75:25 bertambah 0.4\%, sedangkan hasil uji tegangan tarik spesimen 65:35 sebelum direndam sebesar 32.333 MPa setelah direndam turun menjadi 24.46 MPa, tegangan tarik spesimen 70:30 sebelum direndam sebesar 36.3 MPa setelah direndam turun menjadi 34.793 MPa, tegangan tarik spesimen 75:25 sebelum direndam sebesar 32.993 MPa setelah direndam turun menjadi 25.803 MPa,

Kata Kunci-Kata Kunci : Komposit, Perendaman,uji tarik, ASTM.

\section{Pendahuluan}

Sungai Mahakam merupakan sungai terbesar di provinsi Kalimantan Timur yang bermuara di Selat Makassar. Sungai dengan panjang sekitar $920 \mathrm{~km}$ ini melintasi wilayah Kabupaten Kutai Barat di bagian hulu, hingga Kabupaten Kutai Kartanegara dan Kota Samarinda di bagian hilir.Sungai Mahakam sejak dulu hingga saat ini memiliki peranan penting dalam kehidupan masyarakat di sekitarnya sebagai sumber air, potensi perikanan maupun sebagai prasarana transportasi.Sejalan dengan itu, pada tahun 2010 jumlah penduduk Kalimantan Timur yang berprofesi sebagai nelayan tangkap mencapai 167.375 jiwa. Dari jumlah tersebut, terdiri dari 122.308 jiwa adalah nelayan tangkap perikanan laut dan sisanya sebesar 45.067 nelayan tangkap perairan umum.Sehingga produksi ikan di Kalimantan Timur pada tahun 2010 mencapai 159.709 ton [1].

Dengan banyaknya nelayan tangkap di Kalimantan Timur maka kebutuhan akan keberadaan kapal tangkap akan banyak pula. Menurut data dari Kementerian Perikanan dan Kelautan jumlah 33.183 
buah kapal/perahu.Dimana jumlah ini terdiri dari 570,827 buah perahu/kapal penagkap ikan di laut dan 171,542 buah perahu/kapal penagkap ikan di perairan umum [1].

Sampai saat ini sarana yang digunakan di sungai mahakam masih sangat tergantung dari bahan baku kayu. Pemilihan jenis kayu yang digunakan, masih didasarkan kepada pengalaman dan tradisi yang berlaku oleh nenek moyang terdahulu.Jenis yang dipilih umumnya terbatas pada jenis yang sudah dikenal seperti jati (Tectona grandis L.f.), merbau (Intsia bijuga O.Ktz.), kolaka (Parinari corymbosa Miq.), ulin (Eusideroxylon swageri T.et B.), laban (Vitex pubescens Vahl.), rasamala (Altingia exelsa Noronha) dan lainlainnya.Kayu sebagai bahan utama pembuatan kapal diisyaratkan mempunyai kekuatan tertentu, terutama mengenai sifat fisik/mekaniknya.Kayu merupakan material yangbersifat higroskopis yangdipengaruhi kelembaban udarasekitarnya. Kadar air akanberpengaruh terhadap kekuatankayu, semakin kecil kadar air, kekuatan kayu akan bertambah dan juga sebaliknya,

Penggunaan Polimer dan komposit dewasa ini kian meningkat di segala bidang kehidupan seperti untuk pembuatan kapal.Komposit berpenguat serat banyak diaplikasikan pada alat-alat yang membutuhkan material yang mempunyai perpaduan dua sifat dasar yaitu kuat namun juga ringan.Komposit merupakan material alternatif yang dapat digunakan untuk mengurangi ketergantungan terhadap kayu pada produksi kapal. Namun komposit polimer mempunyai sifat akan kemapuan menyerap air jika berada di udara lembab atau ketika polimer tersebut dicelupkan di dalam air (Waterabsorption). Water-absorption pada komposit merupakan salah satu masalah terutama dalam penggunaan komposit di luar ruangan [2].

Tujuan yang hendak dicapai dalam penelitian ini yaitu menganalisa pengaruh perendaman selama 9 hari terhadap kekuatan tarik material komposit resin epoksi tanpa penguat serat dengan perbandingan 65:35, 70:30, 75:25; dan mensimulasikan laju penyerapan air selama 9 hari pada material komposit resin epoksi tanpa penguat serat dengan perbandingan 65:35, 70:30, 75:25.hasil penelitian ini akan menjadi dasar campuran material komposit yang akan direndam

\section{Metode Penelitian}

\section{A. Metode}

Pembuatan papan komposit dengan perbandingan resin dan hardener 65:35, 70:30, dan 75:25 dicetak di Laboratorium Pengujian Bahan jurusan mesin Politeknik Negeri Balikpapan. Material utama dari penelitian ini yaitu, resin tipe epoksi. Resin epoksi dan hardener diperoleh dari PT. Justus Kimia Raya. Resin dicampur dengan hardener dengan perbandingan 65:35, 70:30, dan 75:25. Lalu di cetak menggunakan alat cetak tekan dengan ukuran 200x200x4 mm.

Hasil cetakan yang berupa pelat lalu direndam di dalam wadah yang berisi air sungai Mahakam selama 9 hari. Berdasarkan standar ASTM D570-98 dan data pertambahan berat spesimen diambil tiap 24 jam selama 9 hari. Setelah dilakukan perendaman pelat komposit tersebut dibentuk sesuai standar ASTM D638-02 (type 1) sebanyak 3 spesimen tarik untuk tiap pelat komposit .

\section{B. Gambar Diagram Alir}

Adapun gambar diagram alir penelitian ini dapat dilihat di bawah ini.

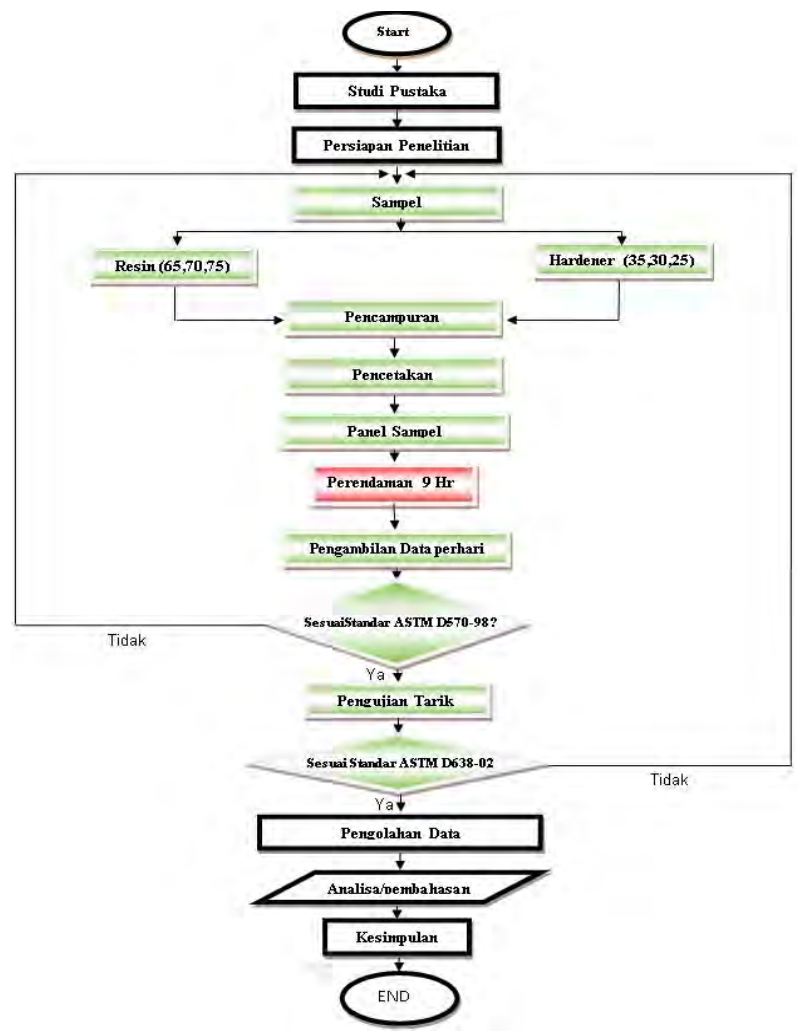

Gambar 1. Diagram metode penelitian 


\section{Hasil dan Pembahasan}

\section{A. Uji Penyerapan Air Sungai Makhakam}

Untuk menentukan besarnya persentase Air sungai yang terserap oleh pelat komposit, yang direndam dengan perendaman selama waktu tertentu. Maka prosedur pengujian penyerapan Air sungai ini mengacu pada ASTM D 570 - 98 [3], sebagai berikut:

$$
\text { . }=\longrightarrow 100 \%
$$

\section{Dimana :}

$$
\begin{aligned}
& = \\
M & =
\end{aligned}
$$

Berdasarkan hasil penelitian terdapat perbedaan berat panel sebelum dan sesudah direndam dalam Air sungai

\begin{tabular}{|c|c|c|c|c|c|c|c|c|c|c|}
\hline \multirow{2}{*}{ No. } & \multirow{2}{*}{ Hari } & \multicolumn{3}{|c|}{ Peuyerapan Air Sungai (gr) } & \multicolumn{3}{|c|}{ Pertambahan Berat (gr) } & \multicolumn{3}{|c|}{ Persentase Berat $(0,9$} \\
\hline & & Panel1 & Panel 2 & Panel 3 & Pavel 1 & Panel 2 & Panel 3 & Panel 1 & Panel 2 & Panel 3 \\
\hline 1 & 2 & 3 & 4 & 5 & 6 & 7 & 8 & 9 & 10 & II \\
\hline & & & & & & & & & & \\
\hline 1 & Berat Awal & 1431 & 1454 & 150 & $a$ & 0 & 0 & 0 & 0 & 0 \\
\hline 2 & 1 & 1455 & 1499 & 1511 & 0.4000 & 0.5000 & 1.1000 & 0.2757 & 0.3347 & 07333 \\
\hline 3 & 2 & 1457 & 1499 & 1511 & 0.0000 & 0.5000 & 1.1000 & 0.4135 & 0.3347 & 0.7333 \\
\hline 4 & 3 & 1458 & 1502 & 1511 & 0.7000 & 0.8000 & 1.1000 & 0.4824 & 05355 & 07333 \\
\hline 5 & 4 & 1455 & 1497 & 1505 & 0.4000 & 0.3000 & 0.5000 & 0.2757 & 0.2008 & 0.3333 \\
\hline 6 & 5 & 145.6 & 1497 & 1505 & 0.5000 & 0.3000 & 0.5000 & 0,3446 & 0.2008 & 0.3933 \\
\hline 7 & 6 & 1456 & 1497 & 1505 & 0.5000 & 0.3000 & 0.5000 & 0.3446 & 0.2008 & 0.3933 \\
\hline 8 & 7 & 1457 & 149.8 & 1506 & 0.0000 & 0.4000 & 0.5000 & 04135 & 0.2677 & 04000 \\
\hline 9 & 8 & 145.7 & 149.8 & 1506 & 0.6000 & 0.4000 & 0.5000 & 04135 & $0.26 \pi$ & 04000 \\
\hline 10 & 9 & 1457 & 149.8 & 1506 & 0.6000 & 0.4000 & 0.0000 & 04135 & $0.26 \pi$ & 04000 \\
\hline
\end{tabular}
dengan lama perendaman selama 9 hari seperti pada Tabel 1 .

Tabel 2. Data Penyerapan Air sungai per hari

Keterangan:

Panel 1 : panel 65:35

Panel 2 : panel 70:30

Panel 3 : panel 75:25

Dari tabel 1 di atas dapat dilihat bahwa makin banyak kandungan resinnya makin berat massa pelat kompositnya hal ini dikarenakan resin memiliki desintas yang besar sehingga jika volume resin bertambah maka bertambah pula berat dari pelat komposit tersebut. Jumlah air yang dapat diserap bergantung kepada jumlah matriks resin yang terdapat pada komposit dan kualitas ikatan antara matriks resin dengan bahan pengisi.

Dari nilai tabel untuk data penyerapan Air sungai pada grafik perbandingan antara persentase penyerapan
Air sungai Vs lama perendaman untuk masing - masing panel seperti pada gambar 2 berikut.

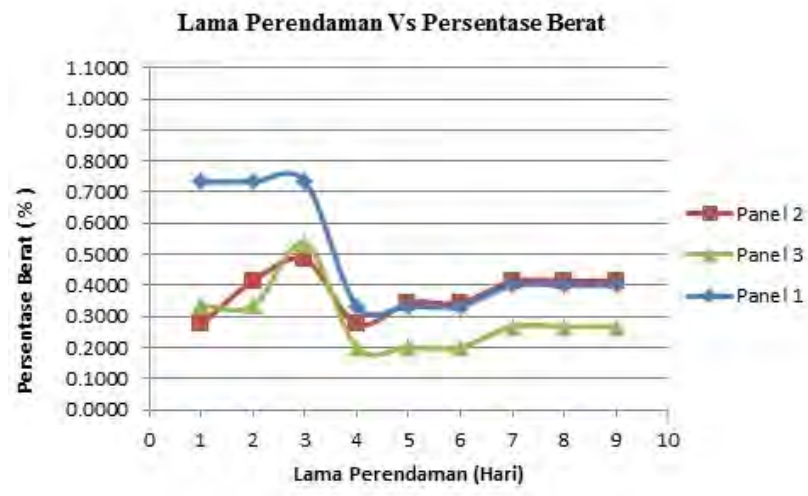

Gambar 2.Pengaruh lama perendaman terhadap persentase penyerapan Air sungai pada material komposit tenunan ramie untuk masing - masing panel.

Berdasarkan Gambar 2 dapat dilihat bahwa persentase penyerapan air sungai meningkat seiring bertambahnya lama perendaman. Dapat dilihat juga bahwa perendaman selama 3 hari merupakan titik penyerapan air tertinggi dan untuk waktu selanjutnya penyerapan air telah stagnan.komposit memiliki sifat yang mampu menyerap air sampai mencapai titik jenuh dalam waktu tertentu. Kapilarisasi terjadi secara hampir linear dan terjadi secara lambat hingga mencapai keadaan jenuh dalam waktu yang lama.

Pertambahan berat dari masing-masing panel komposit sangat berpengaruh terhadap persentase penyerapan Air sungai. Pada Gambar 2 dapat dilihat bahwa semakin lama perendaman juga diikuti pertambahan berat dari masing-masing panel, sehingga persentase penyerapan air sungai semakin naik. Pada panel komposit untuk panel 1, 2 dan 3 terlihat panel 2 memiliki rata-rata persentase penyerapannya yang rendah jika dibandingkan dengan panel lainnya. Sedangkan pada panel 1 memiliki rata-rata persentase pertambahan berat terjadi akibat penyerapan Air sungai secara kapilarisasi yang cukup banyak dicelah komposit tersebut, sehingga berat komposit menjadi bertambah dan lebih berat dari pada panel lainnya. 


\section{B. Uji Tarik}

Pengujian tarik dilakukan pada material yang sebelum dan setelah direndam selama 9 hari.Spesimen uji tarik berdasarkan pada ASTM D638-02 (type 1).

Adapun hasil dari pengujian tarik dari material komposit dengan perbandingan 65:35, 70:30, dan 75:25 dapat dilihat pada gambar 3 di bawah ini.

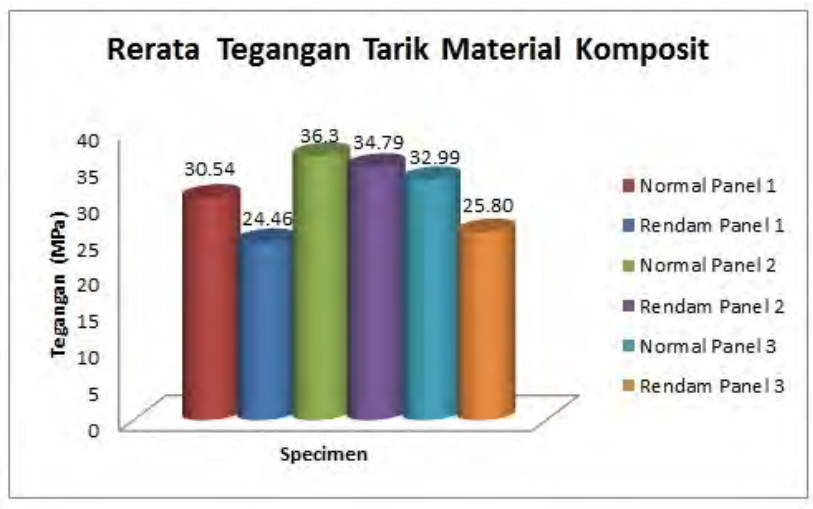

Gambar 3. Diagram Tegangan Tarik Sebelum dan Setelah Direndam

Berdasarkan gambar 3 dapat dilihat bahwa semua panel mengalami penurunan tegangan tarik hal ini disebabkan oleh makin banyak air yang diserap material komposit maka kekuatan tarik material komposit akan ikut menurun. Hal ini dapat terlihat dalam gambar 2 dan gambar 3, bahwa panel 1 dan 3 memiliki rata-rata persentase pertambahan berat yang cukup banyak sehingga panel 1 dan 3 juga memiliki penurunan kekuatan tarik yang cukup besar pula. Sedangkan pada panel 2memiliki rata-rata persentase pertambahan berat yang sedikit sehingga panel 2 memiliki penurunan kekuatan tarik yang tidak signifikan.

\section{Kesimpulan}

Berdasarkan hasil penelitian menunjukkan bahwa:

1. Persentase penyerapan Air sungai meningkat seiring bertambahnya waktu perendaman, pada spesimen 65:35 massanya bertambah $0.4135 \%$, specimen 70:30 bertambah $0.2677 \%$, dan spesimen 75:25 bertambah $0.4 \%$ selama 9 hari perendaman.
2. hasil uji tegangan tarik spesimen 65:35 sebelum direndam sebesar $32.333 \mathrm{MPa}$ setelah direndam turun menjadi $24.46 \mathrm{MPa}$, tegangan tarik spesimen 70:30 sebelum direndam sebesar 36.3 MPa setelah direndam turun menjadi 34.793 MPa, tegangan tarik spesimen 75:25 sebelum direndam sebesar $32.993 \mathrm{MPa}$ setelah direndam turun menjadi $25.803 \mathrm{MPa}$, hal ini disebabkan makin tingginya persentasi penyerapan air sungai, semakin turun juga nilai kekuatan tarik dari material komposit.

\section{Ucapan Terima Kasih}

Kegiatan penelitian ini terlaksana atas bantuan dari pimpinan Politeknik Negeri Balikpapan (Poltekba),baik bantuan dana melalui DIPA Poltekba melalui P3M Poltekba, serta kepada toolman dan admin Program Studi Teknik Alat Berat Poltekba atas bantuannya dalam membantu pengambilan data. Oleh karena itu, kami tak lupa mengucapkan terima kasih.

\section{Daftar Pustaka}

[1] Seketariat Jenderal Kementerian Kelautan dan Perikanan, "Statistik Perikanan Tangkap, Perikanan Budidaya, dan EksporImpor 2003-2010." Kementerian Kelautan dan Perikanan.Jakarta, 2012

[2] Wang, W, Sain, M, Cooper, P.A. "Study of of moisture Absorption in Natural Fiber Plastic Composites." Science and Technology 379-386, 2006.

[3] ASTM. D 570, "Standard test method for water absorption of plastics." American Society for Testing and Materials.Philadelphia, PA. 1998

[4] ASTM. D 638, "Standard Test Method For Tensile Properties of Polymer Matriks Composite Material." American Society for Testing and Materials.Philadelphia, PA. 2002. 